\title{
Measuring accessibility and island development in Ambon City
}

\author{
Andiah Nurhaeny \\ School of Architecture, Planning and Policy Development, Bandung Institute of Technology, \\ Indonesia \\ andiah.nurhaeny@gmail.com (corresponding author)
}

Miming Miharja

School of Architecture, Planning and Policy Development, Bandung Institute of Technology, Indonesia

mimingm@pl.itb.ac.id

\section{Pradono}

School of Architecture, Planning and Policy Development, Bandung Institute of Technology, Indonesia

pradono@pl.itb.ac.id

\section{Puspita Dirgahayani}

School of Architecture, Planning and Policy Development, Bandung Institute of Technology, Indonesia

pdirgahayani@yahoo.com

\begin{abstract}
Island studies has thus far mostly focused on the limitations, isolation and marginality of island communities. However, recent research into island cities, or urban island studies, provides an analytic lens or research perspective that can be used to understand an island's diversity and to encourage researchers to identify island characteristics that have an impact on the function of cities and population centers on islands. One of the factors that inhibit the development of island cities is the limited availability of land area and resources, causing island city regions to depend on other regions to fulfill the population's needs and provide basic services to the population, which puts islands in a vulnerable position because of transportation accessibility problems. This study was conducted using the Transit Opportunity Index (TOI) method to observe the relationship between transportation accessibility and economic growth in island city regions. The result of the analysis showed that transportation accessibility indirectly affects economic growth in every district/city in Maluku Province. Sea transportation accessibility better illustrates the condition of transportation accessibility of Ambon City and other districts/cities in Maluku Province compared to sea and air transportation accessibility.
\end{abstract}

Keywords: Ambon, economic growth, Indonesia, island cities, islands, transportation accessibility

https://doi.org/10.24043/isj.157 • Received June 2020, accepted March 2021

(C) Island Studies Journal, 2021 


\section{Introduction}

Island studies has thus far mostly focused on the limitations, isolation, and marginality of island populations (Baldacchino, 2006; Grydehøj, 2020). However, recent research concerning island cities, or urban island studies, provides an analytic lens or research perspective that can be used to understand the diversity of islands, allowing researchers to see beyond tropes of rurality, remoteness, and backwardness and encouraging them to recognize that some characteristics of islands also have an impact on the functions of cities and population centers. For example, when considering densely populated archipelagos such as Malta or Singapore, it can frequently be beneficial to look at them from a joint urban and island perspective (Grydehøj, 2015).

The present study aims to analyze the relationship between transportation accessibility and economic growth in island cities. Transportation accessibility, defined as ease of movement, is an important factor in supporting economic growth and allows people to move from one place to another in order to fulfill their needs (Maulana \& Farda, 2020). This paper contributes to transportation planning for island city regions, addressing problems related to economic vulnerability, which is a major issue in such regions. We thus ask: "How does transportation accessibility influence economic growth in island cities and the regions around them?"

Grydehøj et al. (2015) break down 'island cities' into the primary categories of "1) major population centres of large islands or archipelagos and 2) densely urbanised small islands or archipelagos." The present paper concerns the second of these categories, and we henceforth use the term 'island cities' to refer specifically to densely populated islands and archipelagos that spatially distant from continental landmasses or large islands.

The main distinguishing characteristics between island cities and continental cities are the dependence on shipping by sea or air and the absence of substantial productive hinterlands. Island cities can be compared to coastal cities and riverfront cities, which can be navigated by boat or ship, but this depends on the size of the island and its proximity to a larger land mass. They can be more limited in their choice of trade and development, because of their dependence on shipping for the supply of goods and the movement of people. Some characteristics that differentiate island cities and continental cities are listed in Table 1.

Table 1. Differences in characteristics of island cities and continental cities. Characteristics derived from Grydehøj, 2015; Grydehøj et al, 2015; Tutt, 2014.

\begin{tabular}{|l|l|l|}
\hline Characteristics & Island Cities & Continental Cities \\
\hline $\begin{array}{l}\text { Location and asset factors } \\
\text { (politically significant, strategic, } \\
\text { commercial) }\end{array}$ & $\begin{array}{l}\text { Degree of physical isolation; } \\
\text { dependence on shipping } \\
\text { and infrastructure development }\end{array}$ & $\begin{array}{l}\text { Better access to the inland } \\
\text { through road networks }\end{array}$ \\
\hline $\begin{array}{l}\text { Demand for built environment } \\
\text { expensive than elsewhere } \\
\text { because of the high cost of } \\
\text { importing labor, materials, etc. }\end{array}$ & $\begin{array}{l}\text { Normally no meaningful } \\
\text { obstacles }\end{array}$ \\
\hline Scale (population, companies) & $\begin{array}{l}\text { Limited by population, labor, } \\
\text { resources, demand, etc. }\end{array}$ & $\begin{array}{l}\text { Unlimited, dependence on } \\
\text { geographical factors, etc. }\end{array}$ \\
\hline $\begin{array}{l}\text { Limitations in resource } \\
\text { development (materials, skills) }\end{array}$ & $\begin{array}{l}\text { A small amount of resources } \\
\text { with high cost of imports }\end{array}$ & $\begin{array}{l}\text { Unlimited, dependence on } \\
\text { geographical factors, etc. }\end{array}$ \\
\hline
\end{tabular}


External factors, such as a country's national development policy, can influence urbanization processes in an archipelago (Larjosto, 2020; Putri \& Salim, 2020; Zhang \& Grydehøj, 2020). Such development policies are implemented in the form of construction projects and the establishment of service centers in the archipelago. Other characteristics, such as geological and geographical factors, also play an important role in pushing population concentration and economic activity. Without good accessibility and location factors, an island will never have a concentration of activities of the island residents.

Island cities that serve as centers of administrative, commercial, or transport activities often become hubs for surrounding islands and even nearby mainland areas. Even when if it is not a major economic power, an island city can have an important position within the local constellation of its region. The growth of urban regions in an archipelago places island cities in a vulnerable position, economically as well as environmentally. One factor that inhibits the development of island cities is limited availability of land area and resources, causing island cities to depend on other regions to fulfill the needs of the population and provide basic services to the population. Meanwhile, the efforts from other regions to meet these needs is hampered due to accessibility issues. The accessibility of island city regions is highly dependent on the availability of a transportation infrastructure.

Accessibility is heavily influenced by the geographical discontinuity of island space (Baldacchino, 2007), necessitating changes of transportation mode, including travelling over sea. Another important factor is accessibility related to public transportation. On land, private transportation can be used when there is no public transportation, but island space being discontinuous makes this alternative more complex (Grydehøj \& Zhang, 2020; Grydehøj \& Casagrande, 2020; Spilanis et al., 2012). For those who lack access to private transportation, there may be other problems in using public transportation, such as limited routes, unfavorable transportation mode changes, long travel times, and security problems. These obstacles are felt more by low-wage households, who tend to travel less and over shorter distances (Bingham \& Zhang, 1997; Lucas, 2004).

Insularity, which creates accessibility challenges, is often considered the most significant obstacle to economic and social development for islands, a problem that is worsened by the fact that the private sector is often uninterested in providing transportation services because of the small size of the market, which leads to unprofitability (Moncada, Briguglio, \& Gordon, 2019). The government can intervene through public service obligation provisions for transportation, where state support is provided in the form of subsidies to reduce the financial burden of the private sector. The provision of different types of transportation and better infrastructure can be a key factor in increasing investment and business productivity. Connectivity enhancement to facilitate trading, which in turn leads to creation of more jobs, by improving connectivity through air and sea, can also open up the tourism potential of an island and facilitate intra-regional trading (Bardolet \& Sheldon, 2008).

\section{A review of the relevant literature}

\section{Transportation accessibility in island cities}

Transportation accessibility is defined in this research as the ease of movement, for example for carrying out activities. The concept of accessibility is based on the notion that transportation is a hereditary need. Mitchell and Rapkin (1954) introduced the idea that the 
number of movements is increased by the number and precise characteristics of activities. Accessibility has been a topic in transportation planning studies since the 1950s, and the concept developed alongside that of mobility. Hansen (1959) defines accessibility as potential opportunities for interaction. Accessibility can also be said to be the opportunity for someone to reach a certain activity location (Linneker \& Spence, 1992).

The biggest difference between mobility and accessibility is that mobility is more focused on transportation system performance, while accessibility focuses on the relationship between transportation systems and land use as part of the analysis (Curtis \& Scheurer, 2010). Litman (2003) states that, traditionally, transportation planning has emphasized the movement of motorized vehicles or people and cargo, while accessibility explicitly influences the relationship between land use and transport and includes number of trips and length of journey as indicators. There is often a trade-off between accessibility and mobility. In line with this, Preston and Rajé (2007) explain the concept of social exclusion in transportation, gaining inspiration from Amartya Sen's (2000) theory. Preston and Rajé (2007) see social exclusion as a constraint-based process that causes the inability of some person or group to participate normally in activities in the community. This inability is not caused by lack of opportunity but by lack of access to opportunity.

Every accessibility measurement has two main parts, i.e. transportation as inhibiting element and activity as element of attraction (Handy \& Niemeier, 1997; Litman, 2003). The transportation element can illustrate whether it is easy or not to carry out the movement. This ease is experienced as the service quality of a transportation system, which can be measured by travelling time, distance, and cost of travel. The activity element illustrates the distribution of various activities that happen in a space and make a location have 'attraction' as a travel destination. The accessibility measurement of both of these elements for island cities can be seen in Table 2.

Table 2. Transportation accessibility in island cities and continental cities.

\begin{tabular}{|l|l|l|l|}
\hline Aspect & Continental City & Island City & Source \\
\hline Mode & Car as main mode & $\begin{array}{l}\text { Sea and air are main modes, } \\
\text { causing multiple changes in } \\
\text { mode in one trip; alternatives } \\
\text { are unavailable due to territorial } \\
\text { isolation }\end{array}$ & $\begin{array}{l}\text { (Baldacchino, 2007; } \\
\text { Luis, 2004; Levy \& } \\
\text { Panou, 2010; Grydehøj } \\
\text { \& Zhang, 2020) }\end{array}$ \\
\hline $\begin{array}{l}\text { Access } \\
\text { Point }\end{array}$ & Road & System nodes and paths & (Levy \& Panou, 2010) \\
\hline $\begin{array}{l}\text { Travel } \\
\text { Time }\end{array}$ & $\begin{array}{l}\text { Can be traveled back } \\
\text { and forth in same day }\end{array}$ & $\begin{array}{l}\text { Possibly requires transit taking } \\
\text { days }\end{array}$ & (Karampela et al, 2014) \\
\hline $\begin{array}{l}\text { Waiting } \\
\text { Time }\end{array}$ & $\begin{array}{l}\text { Definite daily } \\
\text { schedule }\end{array}$ & $\begin{array}{l}\text { Schedule on a weekly time scale } \\
\text { that is often uncertain } \\
\text { depending on the season }\end{array}$ & $\begin{array}{l}\text { (Cross \& Nutley, 1999; } \\
\text { Levy \& Panou, 2010) }\end{array}$ \\
\hline Route & $\begin{array}{l}\text { Cars are alternative } \\
\text { mode for reaching all } \\
\text { urban regions }\end{array}$ & $\begin{array}{l}\text { Very much depends on the } \\
\text { service provided }\end{array}$ & (Levy \& Panou, 2010) \\
\hline Cost & Relatively inexpensive & $\begin{array}{l}\text { High costs due to distance and } \\
\text { mode shifts }\end{array}$ & (Malindretos, 2012) \\
\hline
\end{tabular}


Island city development is limited by the extent to which the city is successful in fulfilling its needs. The unique accessibility of island cities can be seen through the characteristics of the distribution of activities in space as well as the impedance that occur. These two things occur because of spatial discontinuity in island space. Intensity characteristics consist of: (a) activity intensity in island cities is denser in one unit of the same space than in continental cities as a result of limited space; and (b) inter-island transportation needs to increase because of activities that cannot be facilitated by one island alone.

Island spatial discontinuity causes island cities to require greater effort to get the same opportunities as continental cities. Island city accessibility across the sea requires sea or air transportation, which cost more than land transportation (Pelling \& Uitto, 2001). This increases the number of transfers made to reach other islands and decreases the quality of service of inter-island transportation compared to land transportation. Furthermore, high costs of transportation and uncertain shipping schedules can have implications for the per-unit prices of goods that are imported or exported from the island city to become more expensive compared to prices for goods produced on the continent (Briguglio, 1995).

\section{Transportation accessibility measurement methods in island cities}

The existence of transportation causes an increase in population distribution and economic activities. In urban regions, this can be seen in the urban sprawl phenomenon (Spiekermann et al, 2011). However, Linard et al. (2012) note the complexity of the relationship between accessibility and population concentration. Generally, authors who study peripheral areas focus on accessibility index development to measure the extent to which certain places are peripheral. Studies of insular accessibility design measures are basically focused on the transportation supply side.

In an effort to measure island accessibility, Cross and Nutley (1999) developed a measurement method that covers ferry service frequency and travel time as well as other factors that reflect relative comfort from various inter-island transportation modes. The ferry is the most-used mode in the system of inter-island transportation. It has various public features comparable to other public transportation systems. The method developed for urban public transportation accessibility analysis may give interesting options to analyze island transportation with a modification that considers the characteristics of island transportation. The method developed by Mamun et al. (2013), called the Transit Opportunity Index (TOI), takes into account transit accessibility (access level to transit system) and transit connectivity (providing a service system between origin and destination) by combining the size of spatial and temporal coverage and journey time.

Makkonen, Salonen, and Kajander (2013) focused on identification of the spatial differences between population patterns and transportation options in Finland's peripheral islands. The result of the research showed that the ferry supports population distribution, but there was incompatibility between transportation options and population patterns. The deficiency of the accessibility index used in this research is that it did not discuss the cost of ferry transportation. Incorporating two variables in the equation requires a constant value that often erases the ability of accessibility to be widely understood (Schoon, 1999).

With his graph theory approach, Kansky (1963) tried to explore the relationship between transportation network and regional economy characteristics. He developed a transportation network prediction model with the purposes of predicting the distribution of 
transportation routes in terms of the probability of each node (economy activity concentration) to be included in the network. Therefore, the more active the economy of a place, the higher the chance that that it has an extensive transportation network. Even though Kansky (1963) applied his model to predict spatial patterns of railroad and road networks, there is no clear reason why a maritime network could not be analyzed in the same manner as other transportation networks (Ducruet et al., 2010), even if the spatial distribution of sea transportation routes is less restricted by tightly determined boundaries compared to a land network. Of course, in practice, regulations of beach geography, ice density, and depths of certain types of ships impose restrictions on sea traffic, especially in the case of complex shoal archipelagos like Pargas, Finland (Bonsdorff et al., 1997).

\section{Island cities in Indonesia: Ambon City as a case study}

Island cities in Indonesia can be identified by observing areas that simultaneously possess island and urban characteristics. Island criteria refer to limitations related to land area. In Indonesia, an island is considered a land area with limitations if the land area is less than or equal to 2000 $\mathrm{km}^{2}$ (Law No. 27 year 2007 regarding management of coastal areas and small islands). Meanwhile, Indonesia's urban criteria refer to UU No. 26 year 2007 regarding spatial planning: urban regions are areas where the main activity is not farming or other primary sector activity. Concerning the classification of urban regions, the Central Bureau of Statistics states in the Regulation of the Head of BPSN No. 37 year 2010: the primary sector accounts for less than $25 \%$, and the total population is greater than 10,000 inhabitants. In contrast, administrative status is not a variable for determining the nature of a city on an island. The reason is that island regions that do not have the administrative status of a city but have sufficient urban characteristics can be considered island cities (cf. Tutt, 2014). Both these criteria are shown in Table 3.

Table 3. The Criteria of Island Cities in Indonesia.

\begin{tabular}{|l|l|}
\hline Criteria & Indicators \\
\hline Islands & $\begin{array}{l}\text { Island with a land area equal to or less than } 2000 \mathrm{~km}^{2} \text { (Source: Law No. } 27 \text { year } 2007 \\
\text { regarding management of coastal areas and small islands) }\end{array}$ \\
\hline Cities & $\begin{array}{l}\text { Areas with a population of more than 20,000 (Sources: Cohen, 2006; Uchida \& Nelson, } \\
2009)\end{array}$ \\
\hline Cities & $\begin{array}{l}\text { Areas with a population density of more than } 150 \text { per } \mathrm{km}^{2} \text {. (Source: Law No. } 26 \text { year } \\
\text { 2007 regarding spatial planning) }\end{array}$ \\
\hline Cities & $\begin{array}{l}\text { Agriculture or primary sector accounts for less than 25\% of total economic structure } \\
\text { (Source: Regulation of the Head of BPSN No. } 37 \text { year 2010 regarding the classification } \\
\text { of urban and rural regions in Indonesia) }\end{array}$ \\
\hline
\end{tabular}

According to the identification result using the criteria in Table 3, Indonesia has five places that meet the criteria for both islands and cities there are five cities in Indonesia that meet the criteria of island cities: Sabang City, Aceh Province; Batam City, Riau Islands Province; Tarakan City, North Kalimantan Province; Ternate City, North Maluku Province; and Ambon City, Maluku Province. Area size data and urban characteristics from the Central Bureau of Statistics from 2018 can be seen in Table 4. 
Table 4. Island city identification in Indonesia. Source: Central Bureau of Statistics, 2019.

\begin{tabular}{|c|c|c|c|c|c|}
\hline $\begin{array}{l}\text { Criteria for Island } \\
\text { Cities }\end{array}$ & $\begin{array}{l}\text { Sabang/ } \\
\text { Sabang } \\
\text { Island }\end{array}$ & $\begin{array}{l}\text { Batam/ } \\
\text { Batam } \\
\text { Island }\end{array}$ & $\begin{array}{l}\text { Tarakan/ } \\
\text { Tarakan } \\
\text { Island }\end{array}$ & $\begin{array}{l}\text { Ternate/ } \\
\text { Ternate } \\
\text { Island }\end{array}$ & $\begin{array}{l}\text { Ambon/ } \\
\text { Ambon } \\
\text { Island }\end{array}$ \\
\hline \multicolumn{6}{|l|}{ Area } \\
\hline City area $\left(\mathrm{km}^{2}\right)$ & 122.16 & 715.00 & 250.80 & 162.32 & 359.45 \\
\hline Island area $\left(\mathrm{km}^{2}\right)$ & 156.3 & 715.00 & 657.33 & 111.4 & 803.9 \\
\hline \multicolumn{6}{|l|}{ City Characteristics } \\
\hline Population (2018) & 33,978 & $1,283,196$ & 253,026 & 223,111 & 376,152 \\
\hline $\begin{array}{l}\text { Density } \\
\text { (population } / \mathrm{km}^{2} \text { ) }\end{array}$ & 278.14 & 1235 & 384.93 & 1796.67 & 1857.64 \\
\hline $\begin{array}{l}\text { Primary sector } \\
\text { percentage (\%) }\end{array}$ & 3.22 & 3.16 & 11.23 & 3.91 & 4.67 \\
\hline
\end{tabular}

From the five cities identified as island cities in Indonesia, it can be seen that the highest population density is in Ambon City $\left(1,857.64\right.$ inhabitants $\left./ \mathrm{km}^{2}\right)$. Ambon City has a double function as government center and economic center in Maluku Province, in contrast with the other cities, which only function as economic centers (Batam, Tarakan, Ternate), while the provincial government centers are on different islands (Tanjung Pinang, Tanjung Selor, and Sofifi). As we know, a city that is an economic center and a government center has a more important role than a city that only has one of these two aspects. The role of Ambon City as center of the administration as well as center of trading and service activities in Maluku Province gives a complete picture of island city development in Indonesia. In this paper, the research data are at the district/city level, namely Ambon City and the surrounding districts/cities in Maluku Province.

\section{Data and methods}

Economic conditions of Ambon City, Maluku Province

Geographically, Maluku Province consists of several islands that are very dependent on sea transportation, while some harbors do not even have port facilities. Apart from the lack of supporting infrastructure for economic activities, the lack of human resources also contributes to Ambon City's low level of competitiveness. This also causes the poverty level of Maluku Province to be $17.69 \%$, well above the national poverty level of $9.41 \%$ (Central Bureau of Statistics, 2019). However, if you look at the economy of Maluku Province from 2015 until 2018, there was an increase of about 5.44\%. This shows that economic activities of Maluku Province have grown. An overview of the economic conditions of each district/city in Maluku Province in 2018 is presented in Table 5. 
Table 5. Overview of economic conditions of each district/city in Maluku Province in 2018. Note: All movements are from Ambon (i) to the capitals of other regencies/cities (j). Source: Central Bureau of Statistics of Maluku Province, 2019.

\begin{tabular}{|l|l|l|l|l|l|}
\hline $\begin{array}{l}\text { Regency/city in } \\
\text { Maluku Province }\end{array}$ & $\begin{array}{l}\text { Capital } \\
\text { Reg./City }\end{array}$ & $\begin{array}{l}\text { Distance } \\
\text { from } \\
\text { Ambon } \\
\text { (miles) }\end{array}$ & $\begin{array}{l}\text { GDRP } \\
\text { (million Rp) }\end{array}$ & $\begin{array}{l}\text { Distribution } \\
\text { GDRP (\%) }\end{array}$ & $\begin{array}{l}\text { Total } \\
\text { Population }\end{array}$ \\
\hline Ambon City & Ambon & - & $9,826,713.81$ & 33.31 & 461,699 \\
\hline Maluku Tengah & Masohi & 95.85 & $5,541,076.92$ & 18.78 & 372,529 \\
\hline Maluku Tenggara & Langgur & 552.59 & $1,863,697.09$ & 6.32 & 99,591 \\
\hline $\begin{array}{l}\text { Maluku Tenggara } \\
\text { Barat }\end{array}$ & Saumlaki & 584.60 & $1,591,855.76$ & 5.4 & 112,429 \\
\hline Buru & Namlea & 135.09 & $1,475,062.75$ & 5 & 139,658 \\
\hline Seram Bagian Timur & Bula & 270.19 & $1,917,693.54$ & 6.5 & 113,180 \\
\hline Seram Bagian Barat & Piru & 70.20 & $1,863,089.51$ & 6.32 & 170,969 \\
\hline Kepulauan Aru & Dobo & 724.86 & $2,153,277.79$ & 7.3 & 95,005 \\
\hline Maluku Barat Daya & Tiakur & 494.55 & $1,004,857.31$ & 3.41 & 72,840 \\
\hline Buru Selatan & Namrole & 152,00 & $842,548.76$ & 2.86 & 62,271 \\
\hline Tual City & Tual & 165.76 & $1,417,789.54$ & 4.81 & 73,605 \\
\hline Maluku Province & & 552.23 & $29,497,662.79$ & 100 & $1,773,776$ \\
\hline
\end{tabular}

\section{Transportation mode}

As the capital of the province, Ambon City is connected by ferry crossings, ship transport, and air transport to other cities in Maluku Province. Population mobility in Ambon City is divided into internal mobility (intra-island Ambon) and external mobility (inter-island Ambon). External mobility is quite high through the crossing network (express boats, ferries, speedboats), with regular and non-regular operational patterns. The distribution of the three modes of transportation from Ambon City to other cities in Maluku Province is presented in Table 6.

Ambon City has one main harbor for ships belonging to PELNI, Indonesia's national shipping company; two inter-island harbors for speedboats; three harbors for ferries; and two small harbors for speedboats that support movement between Ambon Island and surrounding islands. Yos Sudarso main port serves the movement to all regencies in Maluku Province as well as the surrounding region, among others: South-East Sulawesi, North Maluku, NTT, and West Papua. This inter-land harbor consists of: (a) Old Harbor, which provides connections with Namle (Buru), Namrole (Buru Selatan), and East Seram; and (b) Tulehu Harbor, which provides connections with Masohi and Saparua Island. The ferry crossing harbor consists of: (a) Galala Ferry Harbor, which provides connections with Namlea and Namrole; (b) Liang Ferry Harbor (Hunimua), which provides connections with Kairatu (East Seram) and Masohi; and (c) Waai Ferry Harbor, which provides connections with Haruku island, Saparua island, Nusalaut island, and Masohi. The small harbors consist of: (a) Tulehu Harbor, which provides connections with Saparua island, Haruku island, Nusalaut island and Seram island; (b) Hitu Harbor, which provides connections with the East Seram; and (c) Hila harbor, which provides connections with East Seram. 
Table 6. Distribution of the three modes of transportation from Ambon City to other cities in Maluku Province.

\begin{tabular}{|c|c|c|c|c|c|c|c|c|c|}
\hline \multirow[t]{3}{*}{ Destination } & \multicolumn{9}{|c|}{ Transportation Mode } \\
\hline & \multicolumn{3}{|c|}{ Ferry } & \multicolumn{3}{|c|}{ Ship } & \multicolumn{3}{|c|}{ Airplane } \\
\hline & $\begin{array}{l}\text { Time } \\
\text { (hr) }\end{array}$ & $\begin{array}{l}\text { Cost } \\
\text { (Rp.) }\end{array}$ & Frequency & $\begin{array}{c}\text { Time } \\
\text { (hr) }\end{array}$ & $\begin{array}{l}\text { Cost } \\
\text { (Rp.) }\end{array}$ & Frequency & $\begin{array}{l}\text { Time } \\
\text { (hr) }\end{array}$ & $\begin{array}{l}\text { Cost } \\
\text { (Rp.) }\end{array}$ & Frequency \\
\hline Masohi & 4 & 35 & 2 freq./day & 2 & 1100 & 2 freq./day & & & \\
\hline $\begin{array}{l}\text { Tual City/ } \\
\text { Langgur^ }\end{array}$ & 16 & 650 & 1 freq./day & 22 & 2730 & 1 freq./month & 1.5 & 6500 & 2 freq./day \\
\hline Saumlaki & 24 & 500 & 1 freq./day & 48 & 2900 & 2 freq./month & 1.5 & 6500 & 1 freq./day \\
\hline Namlea & 10 & 780 & 1 freq./day & 10 & 710 & 3 freq./month & 0.5 & 4500 & 1 freq./day \\
\hline Bula & 10 & 1500 & 1 freq./week & & & & & & \\
\hline Piru $\star \star$ & 3 & 5000 & 6 freq./day & & & & & & \\
\hline Dobo & 29 & 1230 & 1 freq./day & 38 & 3000 & 1 freq./month & 1.3 & 6500 & 1 freq./day \\
\hline Tiakur & 48 & 3000 & 1 freq./day & & & & 1.5 & 6500 & 1 freq./day \\
\hline Namrole & 7 & 780 & 1 freq./day & 7 & 680 & 1 time/2 day & 0.5 & 4500 & 1 freq./day \\
\hline
\end{tabular}

Note: $\star$ Tual City and Langgur are in adjacent areas and are connected by crossing mode. On this basis, the accessibility of the two locations was combined in this analysis.

$\star \star$ Access from Ambon to Piru by ferry is not direct but instead uses a bus that first crosses from Huniua Port to Huipirit Port and is then continued with other land modes.

Apart from sea transportation, there is also air transportation through Pattimura Airport, which is an international airport with low numbers of flights and routes. Pattimura Airport is the center for air transportation, with internal distribution through the routes in the western, southern, southeastern and northern regions of the Maluku region. Areas and cities that are flight destinations in Maluku Province are Ambon City, Amahai, Wahai, Bula, Namrole, Namlea, Kisar, Saumlaki, Larat, Tual, Dobo, and Banda. The highest flight frequency is for Ambon-Tual, followed by Ambon-Saumlaki. Other air transportation support is provided by unscheduled air transport, providing travel to East Seram. Flights to Namrole and Namlea on Buru Island are served by so-called 'pioneer flights', while East Seram is served by charter flights.

\section{Methods}

The first step of this analysis was to assess the relative weight of each of the cities in Maluku Province by following Kansky's (1963) predictive model of network structures. In this research, the concept of 'relative probability to become part of the network' (Kansky, 1963) is understood as the relative weight of a certain island (i.e. economy activity concentration). Relative weight assessment was obtained as follows:

\section{Relative Weight $=($ GDRP City/PDRB Maluku Province $)$}

Until now, no index has been agreed upon for calculating accessibility. In this study, we use a modification of the accessibility index model proposed by Schoon (1999). This model tries to calculate the relative value of a mode against the choice of other modes at each point of origin and destination. Apart from the different application settings, we chose to use this index because it fulfills important theoretical criteria that we deem necessary to measure transportation opportunities in an island nation. Besides travel time (or distance), this index 
takes into account the frequency of transportation. In this case, we borrowed the calculations made in the Transit Opportunity Index (TOI) (Mamun et al., 2013) and used these as the basis for the following accessibility index assessment:

$\mathrm{AI}=($ frequency $(1) /$ time $(1))+($ frequency $(2) /$ time $(2))+($ frequency $(1) /$ time $(1)))) / \Sigma$ (frequency ()$/$ time ()$)$

\section{Discussion of the results}

The results of the relative weight assessment based on the Gross Domestic Regional Product of Ambon Municipality by Category at Constant 2000 Market Price (Billion Rupiahs) Contribution for Each District/City in Maluku Province in 2018, presented in Table 7, show that the first rank was obtained by Ambon City, followed by Masohi and Tual City. All three have a ferry crossing network that has daily scheduled routes, thereby illustrating the movement in urban regions, with Ambon City as its center.

Table 7. Relative weight assessment of each regency/city in Maluku Province.

\begin{tabular}{|l|l|l|l|}
\hline No. & Capital Regency/City & Relative Weight & Rank \\
\hline 1 & Ambon City & 0.333 & 1 \\
\hline 2 & Masohi & 0.188 & 2 \\
\hline 3 & Tual City/Langgur & 0.111 & 3 \\
\hline 4 & Saumlaki & 0.054 & 4 \\
\hline 5 & Namlea & 0.050 & 5 \\
\hline 6 & Bula & 0.065 & 6 \\
\hline 7 & Piru & 0.063 & 7 \\
\hline 8 & Dobo & 0.073 & 8 \\
\hline 9 & Tiakur & 0.034 & 9 \\
\hline 10 & Namrole & 0.029 & 10 \\
\hline
\end{tabular}

An overview of the average travel time and average cost per transportation mode in Maluku Province can be seen in Figures 1 and 2.

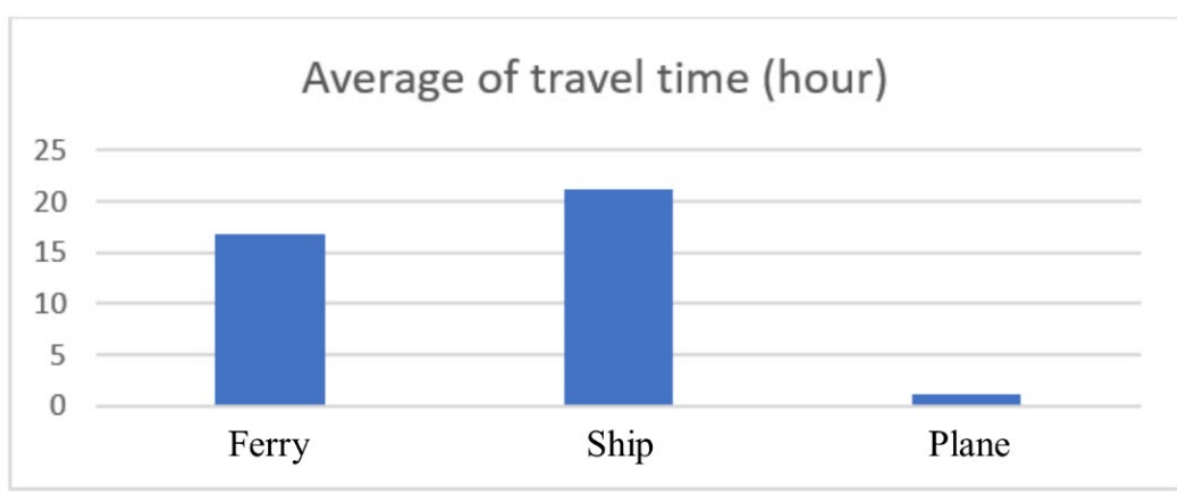

Figure 1. Average of travel time by mode of transportation in Maluku Province. 


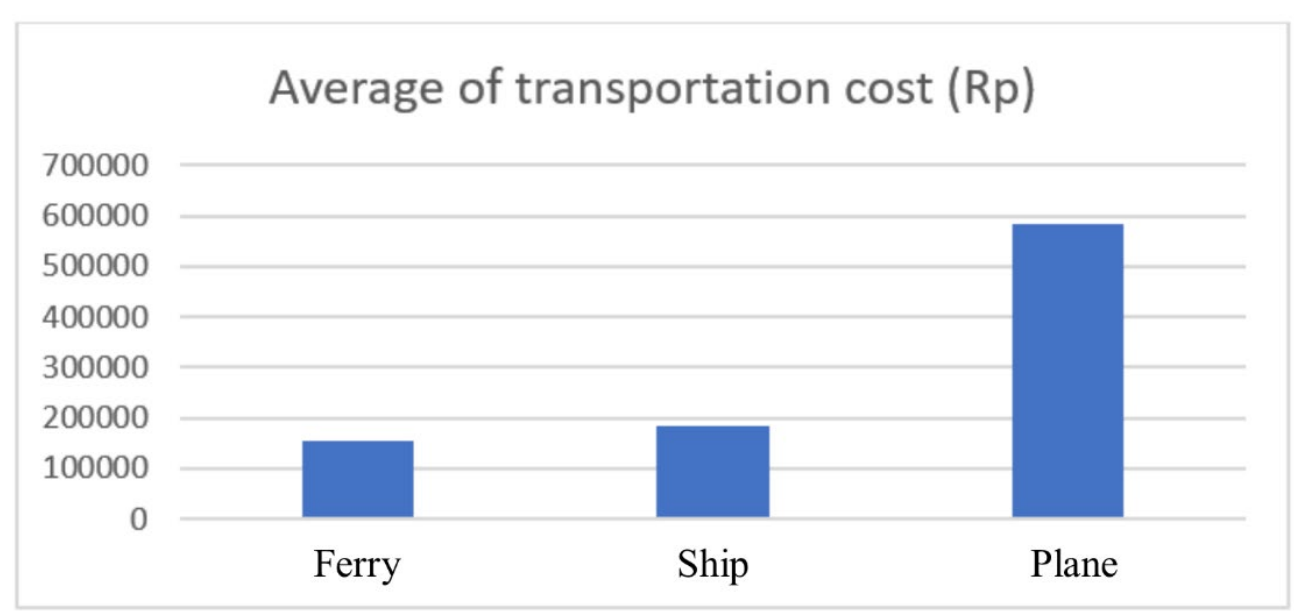

Figure 2. Average of transportation cost per mode of transportation in Maluku Province.

In servicing trips, air mode (airplanes) cuts travel time significantly, especially compared to the two sea modes, serving the islands up to 10 times faster. But this reduction in travel time is also directly proportional to the cost, which is up to five times higher. Because of this, airplanes can only be accessed by middle- and upper-class passengers. Movement using planes is not a common practice for islanders in Maluku Province. The accessibility index based on regency/city in Maluku Province is presented in Table 8.

Table 8. Accessibility index based on regencies/cities in Maluku Province.

\begin{tabular}{|l|l|l|}
\hline Destination & $\begin{array}{l}\text { Accessibility Index } \\
\text { (sea mode and air mode) }\end{array}$ & $\begin{array}{l}\text { Accessibility Index } \\
\text { (sea mode) }\end{array}$ \\
\hline Masohi & 0.1208 & 0.1208 \\
\hline Tual City/Langgur & 0.1125 & 0.0052 \\
\hline Saumlaki & 0.0572 & 0.0035 \\
\hline Namlea & 0.1699 & 0.0089 \\
\hline Bula & 0.0817 & 0.0012 \\
\hline Piru & 0.1611 & 0.1611 \\
\hline Dobo & 0.0648 & 0.0028 \\
\hline Tiakur & 0.0538 & 0.0001 \\
\hline Namrole & 0.1783 & 0.0173 \\
\hline
\end{tabular}

Transport accessibility via sea mode and air mode

It cannot be said that transportation accessibility directly influences GDRP in each district/city in Maluku Province. Sea accessibility better describes the condition of transportation accessibility in Ambon City and districts/cities in Maluku Province compared to the accessibility of sea and air transportation. A comparison between both based on the accessibility indexes is presented in Table 9. 
Table 9. Ranking of accessibility indexes for each capital of regency/city in Maluku Province. Source: Analysis results (2019).

\begin{tabular}{|l|l|l|l|l|l|l|l|}
\hline No. & Destination & $\begin{array}{l}\text { Accessibility } \\
\text { Index } \\
\text { (sea mode and } \\
\text { air mode) }\end{array}$ & Rank & $\begin{array}{l}\text { Accessibility } \\
\text { Index } \\
\text { (sea mode) }\end{array}$ & Rank & $\begin{array}{l}\text { Relative } \\
\text { Weight }\end{array}$ & Rank \\
\hline 1 & Masohi & 0.120790 & 4 & 0.120790 & 2 & 0.188 & 1 \\
\hline 2 & Tual/Langgur & 0.112523 & 5 & 0.005155 & 5 & 0.111 & 2 \\
\hline 3 & Saumlaki & 0.057151 & 8 & 0.003467 & 6 & 0.054 & 6 \\
\hline 4 & Namlea & 0.169911 & 2 & 0.008858 & 4 & 0.050 & 7 \\
\hline 5 & Bula & 0.081677 & 6 & 0.001150 & 8 & 0.065 & 4 \\
\hline 6 & Piru & 0.161053 & 3 & 0.161053 & 1 & 0.063 & 5 \\
\hline 7 & Dobo & 0.064791 & 7 & 0.002847 & 7 & 0.073 & 3 \\
\hline 8 & Tiakur & 0.053796 & 9 & 0.000112 & 9 & 0.034 & 8 \\
\hline 9 & Namrole & 0.178308 & 1 & 0.017256 & 3 & 0.029 & 9 \\
\hline
\end{tabular}

The mode of sea transportation is usually the main mode of connection between islands and the mainland or other islands (Rigas, 2009). This is because travel by sea tends to be favored by passengers who have a lot of time and a limited budget, while air transportation is preferred by passengers who are sensitive to travel time or travel longer distances (Rigas, 2009).

\section{Conclusion}

Based on the results of the analysis in this study, transportation accessibility from Ambon City to districts/cities in Maluku Province does not directly reflect the economic growth of each district/city in Maluku Province. In addition, the analysis showed that the accessibility of sea transportation can better describe the condition of transportation accessibility in Ambon City and districts/cities in Maluku Province compared to the accessibility of sea and air transportation combined. This study indicates that the district/city scale is too large to assess the relationship between transportation accessibility and economic growth. In addition, districts/cities that combine many islands into one unit render many island characteristics invisible in the data. Therefore, further research needs to be done using a reduced scale of observation, i.e. limited to Ambon City.

As an island city, Ambon, with its service and trade activities, functions as a trade and service center and transportation hub for its surrounding cities. This city type does not have huge economic power but holds an important position within its local constellation power relations. Future research should thus observe the effect of multimodal accessibility performance from the island city to various surrounding island ports in supporting the role of an island city as a hub and collection center for distribution across the archipelagic region. There is still an opportunity to further study the development of island cities from regional and urban planning perspectives, including with respect to population and economy, environmental and land use systems, and transportation systems and infrastructure. 


\section{Acknowledgements}

The first author would like to thank the Indonesia Endowment Fund for Education (LPDP), as the full-ride scholarship from the Indonesian Ministry of Finance, for supporting the first author as a doctoral candidate at Bandung Institute of Technology. The first writer also wishes to thank Adam Grydehøj and Patricia Adrienne Tutt for providing time and advice and for answering questions on island cities.

\section{References}

Baldacchino, G. (2006). Managing the hinterland beyond: Two ideal-type strategies of economic development for small island territories. Asia Pacific Viewpoint, 47(1), 45-60. https://doi.org/10.1111/j.1467-8373.2006.00295.x

Baldacchino, G. (2007). Fixed links and the engagement of islandness: Reviewing the impact of the Confederation Bridge. Canadian Geographer, 51(3), 323-336. https://doi.org/10.1111/j.1541-0064.2007.00181.x

Bardolet, E., \& Sheldon, P. J. (2008). Tourism in archipelagos. Hawai'i and the Balearics. Annals of Tourism Research, 35(4), 900-923. https://doi.org/10.1016/j.annals.2008.07.005

Bingham, R. D., \& Zhang, Z. (1997). Poverty and economic morphology of Ohio centralcity neighborhoods. Urban Affairs Review, 32(6), 766-796. https://doi.org/10.1177/07399863870092005

Bonsdorff, E., Blomqvist, E. M., Mattila, J., \& Norkko, A. (1997). Coastal eutrophication: Causes, consequences and perspectives in the archipelago areas of the Northern Baltic Sea. Estuarine, Coastal and Shelf Science, 44(SUPPL. A), 63-72. https://doi.org/10.1016/S0272-7714(97)80008-X

Briguglio, L. (1995). Small Island Developing States and their economic vulnerabilities. World Development, 23(9), 1615-1632. https://doi.org/10.1111/j.1467-8373.2006.00295.x

Cross, M., \& Nutley, S. (1999). Insularity and accessibility: The small island communities of Western Ireland. Journal of Rural Studies, 15(3), 317-330. https://doi.org/10.1016/S0743-0167(98)00062-X

Curtis, C., \& Scheurer, J. (2010). Planning for sustainable accessibility: Developing tools to aid discussion and decision-making. Progress in Planning, 74(2), 53-106. https://doi.org/10.1016/j.progress.2010.05.001

Ducruet, C., Rozenblat, C., \& Zaidi, F. (2010). Ports in multi-level maritime networks: evidence from the Atlantic ( 1996 - 2006 ). Journal of Transport Geography, 18(4), 508518. https://doi.org/10.1016/j.jtrangeo.2010.03.005

Grydehøj, A. (2020). Critical approaches to island geography. Area, 52(1), 2-5. https://doi.org/10.1111/area.12546

Grydehøj, A. (2015). Island city formation and urban island studies. Area, 47(2015), 429-435. https://doi.org/10.1111/area.12207

Grydehøj, A., \& Casagrande, M. (2020). Islands of connectivity: Archipelago relationality and transport infrastructure in Venice Lagoon. Area, 52(1), 56-64.

https://doi.org/10.1111/area.12529 
Grydehøj, A., Pinya, X. B., Cooke, G., Doratlı, N., Elewa, A., Kelman, I., Pugh, J., Schick, L., \& Swaminathan, R. (2015). Returning from the horizon: Introducing urban island Studies. Urban Island Studies, 1, 1-19. https://doi.org/10.20958/uis.2015.1

Grydehøj, A., \& Zhang, H. (2020). Complementarity of island cross-sea transport links: Bridges, ferries, and mobility in Zhoushan Archipelago, China. Journal of Marine and Island Cultures, 9(2), 49-63. https://doi.org/10.21463/jmic.2020.09.2.04

Handy, S. L., \& Niemeier, D. A. (1997). Measuring accessibility: An exploration of issues and alternatives. Environment and Planning A, 29(7), 1175-1194. https://doi.org/10.1068/a291175

Hansen, W. G. (1959). How Accessibility Shapes Land Use. Journal of the American Planning Association, 25(2), 73-76. https://doi.org/10.1080/01944365908978307

Hernández Luis, J. Á. (2004). The role of inter-island air transport in the Canary Islands. Journal of Transport Geography, 12(3), 235-244. https://doi.org/10.1016/j.jtrangeo.2004.04.005

Kansky, K.J. (1963). Structure of transportation networks: Relationship between network geometry and regional characteristics. Kotavaara.

Karampela, S., Kizos, T., \& Spilanis, I. (2014). Accessibility of islands: Towards a new geography based on transportation modes and choices. Island Studies Journal, 9(2), 293-306.

Larjosto, V. (2020). Islands of the Anthropocene. Area, 52(1), 38-46.

Levy, S., \& Panou, C. (2010). To Travel or Not To Travel: a Study of Islanders'Trips To the Mainland. 12th WCTR, July 11-15, 2010 - Lisbon, Portugal, 1-15 .http://intranet.imet.gr/portals/0/usefuldocuments/documents/01579.pdf

Linard, C., Gilbert, M., Snow, R. W., Noor, A. M., \& Tatem, A. J. (2012). Population distribution, settlement patterns and accessibility across Africa in 2010. PLoS ONE, 7(2). https://doi.org/10.1371/journal.pone.0031743

Linneker, B. J., \& Spence, N. A. (1992). Accessibility Analysis of the Impact of the M25 London Orbital Motorway on Britain. Environment and Planning A, 24, 1137-1154. https://doi.org/10.1068/a241137

Litman, T. (2003). Measuring transportation: Traffic, mobility and accessibility. 73(10), 28-32.

Makkonen, T., Salonen, M., \& Kajander, S. (2013). Island accessibility challenges: Rural transport in the Finnish archipelago. European Journal of Transport and Infrastructure Research, 13(4), 274-290.

Malindretos, G. (2012). Logistics in small islands: challenges for sustainable supply chain solutions. 2nd International Conference on Supply Chains Logistics.

Mamun, S. A., Lownes, N. E., Osleeb, J. P., \& Bertolaccini, K. (2013). A method to define public transit opportunity space. Journal of Transport Geography, 28, 144-154. https://doi.org/10.1016/j.jtrangeo.2012.12.007

Maulana, A., \& Farda, M. (2020). Improving the Accessibility of the West Java Southern Area through Collector Road Widening. International Journal of Sustainable Transportation Technology, 3(1), 1-6. https://doi.org/10.31427/ijstt.2020.3.1.1

Mitchell, R. B., \& Rapkin, C. (1954). A Function of Land Use. Urban Traffic.

Moncada, S., Briguglio, M., \& Gordon, C. (2019). A primer on building successful economic environments on islands. The 21st Century Maritime Silk Road islands economic cooperation forum annual report on global islands. Island Studies Press. 
Pelling, M., \& Uitto, J. I. (2001). Small island developing states: Natural disaster vulnerability and global change. Environmental Hazards, 3(2), 49-62. https://doi.org/10.3763/ehaz.2001.0306

Preston, J., \& Rajé, F. (2007). Accessibility, mobility and transport-related social exclusion. Journal of Transport Geography, 15(3), 151-160. https://doi.org/10.1016/j.jtrangeo.2006.05.002

Putri, H., \& Salim, W. (2020). The Maritime Silk Road's potential effects on outer island development: The Natuna Islands, Indonesia. Island Studies Journal, 15(2), 155-172. https://doi.org/10.24043/isj.136

Rigas, K. (2009). Boat or airplane? Passengers' perceptions of transport services to islands. The example of the Greek domestic leisure market. Journal of Transport Geography, 17(5), 396-401. https://doi.org/10.1016/j.jtrangeo.2008.07.005

Sen, A. (2001). Social exclusion: Concept, application, and scrutiny. Social Development Papers, No. 1, Office of Environment and Social Development, Asian Development Bank.

Spiekermann, K., Wegener, M., Kvêtôn, V., Marada, M., Schürmann, C., Biosca, O., Segul, A., Antikainen, H., Kotavaara, O., Rusanen, J., Bielanska, F., Fermi, F., Fiorello, D., Komornicki, T. and Rosik, P. (2011). TRACC-Transport Accessibility at Regional/Local Scale and Patterns in Europe. ESPON.

Spilanis, I., Kizos, T., \& Petsioti, P. (2012). Accessibility of Peripheral Regions: Evidence from Aegean Islands (Greece). Island Studies Journal, 7(2), 199-214.

Tutt, P. A. (2014). Defining the island city: ancient right versus modern metropolis, as considered at Peel, Isle of Man. Island Studies Journal, 9(2), 191-204.

Zhang, H., \& Grydehøj, A. (2020). Locating the interstitial island: Integration of Zhoushan Archipelago into the Yangtze River Delta urban agglomeration. Urban Studies, 0042098020937987. https://doi.org/10.1177/0042098020937987 